\title{
The Effects of Coriandrum sativum L. and Chaerophyllum macropodum Boiss. (Apiaceae) on human plasma angiotensin-converting enzyme (ACE) in vitro
}

\author{
Fatih Çağlar ÇELIKKEZEN*1, Vedat TÜRKOĞLU², Mehmet FIRAT², Zehra BAŞ² \\ ${ }^{1}$ Bitlis Eren University, Faculty of Arts and Sciences, Department of Chemistry, Bitlis, Turkey. \\ ${ }^{2}$ Van Yuzuncu Yll University, Faculty of Science, Department of Chemistry, Van, Turkey. \\ (ORCID: 0000-0001-5489-7384) (ORCID: 0000-0002-0935-1195) (ORCID: 0000-0001-5814-614X) (ORCID: \\ 0000-0002-4071-9744)
}

\begin{abstract}
Hypertension is a very important problem around the world. The inhibition of the Angiotensin-converting enzyme (ACE, EC.3.4.15.1.) is regarded as fundamental of hypertension treatment. However, synthetic ACE inhibitors have several side effects. For this reason, there are lots of studies to improve green ACE inhibitors. Therefore, this study was designed to determine the potential inhibitory effects of two members of Apiaceae, Coriandrum sativum and Chaerophyllum macropodum, on human plasma ACE. For this purpose, water extracts of the plants were used. ACE inhibition activity was detected spectrophotometrically. Both plant extracts showed an inhibitory effect on ACE activity. The obtained results showed that Coriandrum sativum and Chaerophyllum macropodum have inhibitory effects on human plasma $\mathrm{ACE}$ with an $\mathrm{IC}_{50}$ value of $0.7 \mathrm{mg} / \mathrm{mL}$ and $1.14 \mathrm{mg} / \mathrm{mL}$, respectively. Lineweaver-Burk graph was used to determine the inhibition type. The inhibition types were found as reversible noncompetitive. According to the obtained results, Coriandrum sativum and Chaerophyllum macropodum are valuable functional food with ACE inhibition capacity which may be used to balance blood pressure efficiently.
\end{abstract}

Keywords: Hypertension, Angiotensin-converting enzyme I, Coriandrum sativum, Chaerophyllum macropodum, Apiaceae

\section{Coriandrum sativum L. ve Chaerophyllum macropodum Boiss. (Apiaceae)'nin in vitro İnsan Plazma Anjiyotensin Dönüştürücü Enzim Üzerine Etkileri}

\begin{abstract}
$\ddot{\mathbf{O} z}$
Hipertansiyon dünya çapında çok önemli bir problemdir. Anjiyotensin dönüştürücü enzimin (ACE, EC.3.4.15.1.) inhibisyonu, hipertansiyon tedavisinin temeli olarak kabul edilir. Ancak sentetik ACE inhibitörlerinin bazı yan etkileri vardır. Bu nedenle, doğal ACE inhibitörleri geliştirmek için birçok çalışma yapılmaktadır. Bu sebeple, bu çalışma, Apiaceae'nin iki üyesi olan Coriandrum sativum ve Chaerophyllum macropodum'un insan plazma ACE'si üzerine potansiyel inhibitör etkilerini belirlemek için tasarlanmıştır. $\mathrm{Bu}$ amaçla, bitkilerin su ekstraktları kullanılmıştır. ACE inhibisyon aktivitesi spektrofotometrik olarak tespit edildi. Her iki bitki özütü de ACE aktivitesi üzerinde inhibe edici etki gösterdi. Elde edilen sonuçlar, Coriandrum sativum ve Chaerophyllum macropodum'un sırasıyla $0,7 \mathrm{mg} / \mathrm{mL}$ ve $1,14 \mathrm{mg} / \mathrm{mL} \mathrm{IC}_{50}$ değeriyle insan plazma ACE üzerine inhibe edici etkilere sahip olduğunu gösterdi. İnhibisyon tipini belirlemek için Lineweaver-Burk grafiği kullanıldı. İnhibisyon türleri geri dönüşümlü, yarışmasız inhibisyon olarak bulundu. Elde edilen sonuçlara göre, Coriandrum sativum ve Chaerophyllum macropodum'un ACE inhibisyon kapasitesine sahip, kan basıncını etkin bir şekilde dengelemek için kullanılabilecek, değerli fonksiyonel gıdalardır.
\end{abstract}

Anahtar kelimeler: Hipertansiyon, Anjiyotensin dönüştürücü enzim I, Coriandrum sativum, Chaerophyllum macropodum, Apiaceae

\footnotetext{
${ }^{*}$ Corresponding author: celikezen@gmail.com
}

Received: 10.03.2021, Accepted: 06.06.2021 


\section{Introduction}

Hypertension is very important health problem causing death around the World, and it is associated with coronary diseases [1]. Pathogenesis of this disease has indicated that the angiotensin-converting enzyme (ACE) is a powerful regulator for the balance of blood pressure [2]. ACE is a peptidase in the reninangiotensin system (RAS) which transforms angiotensin I into the angiotensin II [3]. RAS has a central role in the regulation of peripheral electrolyte homeostasis and blood pressure in mammalians [4]. Juxtaglomerular cells of the kidney release renin regulating the decrease in blood pressure and volume of the kidney [5]. Renin helps in the formation of angiotensin I [6]. However, the blocking of ACE activity suppresses the angiotensin II production and reduces blood pressure. In this way, ACE inhibitors are used to treat hypertension in medicine [7]. Today, several ACE inhibitors are in use clinically to treat hypertension, which includes captopril, lisinopril, and temocapril. But synthetic ACE inhibitors have several adverse impacts such as coughing, rashes, and taste aversion [8]. For this reason, research interests have focused on ACE inhibitors from natural sources including plants [9,10]. It has been reported that some plant extracts showed the inhibition effect on ACE, such as Glycine max [11], Cassia tora [12], Rosa damascene [13], and Thymbra sintenisii [14].

Apiaceae is known as a large plant family which includes 3780 species in 434 genera [15]. Apiaceae family is generally seen in the northern area and Mediterranean countries [16]. Approximately, 101 genera including 451 species of this family have been determined in Turkey [17], and the members of this family are used in cosmetics including perfumery and pharmaceutical industries $[16,18]$.

Chaerophyllum genus of Apiaceae shows distinctive fragrant character, by this way, they are used in preparations of food, such as flavoring in cheese production, and also consumed as an edible vegetable in Turkey and Iran [19-21]. Chaerophyllum macropodum (C. macropudum) is traditionally mixed into herby cheese which is a famous dairy product for its aroma and flavor in Turkey [21]. But there is limited knowledge about the bioactivity of $C$. macropodum. The studies on Chaerophyllum species have shown that it has phenylpropanoids, phenolic acids, flavonoid glycosides, and polyacetylenes [22]. In addition, there are some reports that indicate chemical composition, antioxidant and antimicrobial effects of $C$. macropodum [20-22]. To our best knowledge, there is no report about the inhibitory effect of $C$. macropodum on ACE activity.

Coriandrum sativum L. (C. sativum), another member of the family Apiaceae, is a biennial herb. C.sativum is cultivated in Asia, Europe, and North Africa and green leaves of $C$. sativum are a rich source of minerals, vitamins and iron [23]. Its seed oil is widely used in cosmetic, soft drink, food, and chocolate industries [24]. C. sativum is traditionally used to treat disorders such as respiratory, urinary systems disorders, diabetes, inflammation, and anxiety [25-27]. In addition, it has been stated that $C$. sativum has analgesic [28], anti-insulin resistance activity [29], and antihypertensive properties [30].

As far as we know, there is no study about the inhibition effects of $C$. sativum and $C$. macropodum on human plasma ACE activity in vitro. Thus, the present study was designed to investigate the inhibition properties of $C$. sativum and C. macropodum on human plasma ACE in vitro for the first time.

\section{Material and Methods}

\subsection{Plant Material}

Chaerophyllum macropodum Boiss. was collected in Diz Stream of Hakkari Cilo mountain at 1730m. in May. Coriandrum sativum L. was collected at $850 \mathrm{~m}$ in Siirt Kurtalan in June. Scientific diagnoses of the plants were made by Mehmet FIRAT from Van Yuzuncu Yil University, Faculty of Education, Department of Biology

\subsection{Plant Extraction}

After the plant samples were dried properly, they were ground into a fine powder with the help of a blender. Then, $90 \mathrm{~mL}$ of hot water was added by weighing $10 \mathrm{~g}$ of each of the plant samples and kept at room temperature until it cools down. Then, it was used fresh by filtering through filter paper. Stock solutions were stored at $+4{ }^{\circ} \mathrm{C}$ [31]. Minor modification were made to the method. 


\subsection{Preparation of the human plasma}

Blood samples were taken from the Van Red Crescent Blood Center of Turkey. The samples were added into tubes including EDTA and centrifuged at $1500 \mathrm{rpm}$ for 15 minutes. Obtained plasma was centrifuged again for 1 hour $\left(40{ }^{\circ} \mathrm{C}, 8500 \mathrm{rpm}\right)$ to uproot the ghosts and intact cells. Plasma samples were then stored [14]

\subsection{Determination of ACE Activity}

The ACE activity was determined according to Holmquist et al. (1979). Fifty mM HepesNa buffer, 0.3 $\mathrm{M} \mathrm{NaCl}, 10 \mu \mathrm{M} \mathrm{ZnCl}_{2}$, and $1 \mathrm{mM}$ FAPGG were added to the assay cuvette. One unit of activity was defined as the quantity of $\mathrm{ACE}$ that produces a $\triangle \mathrm{A} 345 / \mathrm{min}$ of $1.0[32,33]$.

\subsection{ACE Inhibition Assay}

The experiments were carried out in the laboratories of the Van YYÜ Chemistry Department. In the test, human plasma was used to evaluate ACE activity. Two experimental tubes were received as blank and sample. Then, $100 \mu \mathrm{L}$ of plasma containing ACE was added to each tube. After this, $900 \mu \mathrm{L}$ of HEPES buffer (50 mM HEPES, $0.3 \mathrm{M} \mathrm{NaCl}, 10 \mu \mathrm{M} \mathrm{ZnCl}_{2} \mathrm{pH} 7.5$ ) was put into the blank tube and stirred. The spectrophotometer (Shimadzu $1800 \mathrm{UV}$-Vis) was reset with a blank tube. Fifty mM HEPES buffer (pH 7.5), inhibitor (plant extracts), and $1 \mathrm{mM}$ substrate (FAPGG) were added to the sample tube (total volume $1000 \mu \mathrm{L}$ ) and stirred. Different concentrations of $C$. sativum and C. macropodum extracts (at 0 , $0.25,0.5,0.75,1 \mathrm{mg} / \mathrm{mL}$ ) were used. The absorbance value was read at $345 \mathrm{~nm}$. The sample tube was incubated for 30 minutes at $35^{\circ} \mathrm{C}$. After the waiting time, the absorbance of the tubes was determined at $345 \mathrm{~nm}$. The reduction in absorbance was calculated.

A $($ ACE Activity $)=(\Delta \mathrm{OD} / 0.517) \times(\mathrm{Vc} / \mathrm{Ve}) \times \mathrm{f}$

$\triangle \mathrm{OD}$ : Difference between optic densities at $345 \mathrm{~nm}$ for per minute

Vc: Whole volume

Ve: Volume of enzyme solution (plasma hemolysate)

f: Dilution factor

$0.517 \mathrm{mM}^{-1} \mathrm{~cm}^{-1}$ : Extinction coefficient of FAPGG

The inhibition activity of ACE was found from the calibration curve and calculated via the following equation:

$\%$ ACE inhibition = Uninhibited activity - Inhibited activity / Uninhibited activity x100

In this study, the inhibition affects $C$. sativum and C. macropodum plants on the ACE enzyme in human plasma was investigated. Extracts of both plants showed a reversible-noncompetitive inhibition effect on $\mathrm{ACE}$. Inhibition type and $\mathrm{IC}_{50}$ values were determined from Lineweaver-Burk and $\%$ Activity versus inhibitor concentration graphs for each plant extract.

\section{Results and Discussion}

Hypertension is identified an important health problem which affects one billion people around the world [34]. Moreover, it is known as a "silent killer" due to its asymptomatic affect in adults [35]. It has been reported that the inhibition of ACE is an important way of hypertension treatment. This enzyme is zinc-dependent metallopeptidase that transforms angiotensin I to angiotensin II and promotes the degradation of vasodilator bradykinin [36]. In addition, it has been stated that hypertension may be prevented by ACE inhibitors [37]. These inhibitors are shown as the first step for the treatment of hypertension, myocardial infarction and heart failure [38]. At this point, ACE inhibitors may effectively reduce blood pressure, but synthetic medications can cause some adverse effects [39,40]. Recently, there is a considerable interest in green components for treatment of hypertension [41].

These plants which are used in folk medicine have been used to treat some illness in all civilizations. These medicinal plants are popular because of their efficiency, cheapness, and few adverse effects. It has been reported that more than two thousand plants have been identified as a medicinal herb for the treatment of hypertension including cardioprotective, cardioactive, cardiotonic, or circulatory stimulating activities [42]. Moreover, it has been concluded that bioactive components that are available 
in foods and medicinal plants prevent cardiovascular health [43]. These components such as phenolic acids, alkaloids, polyphenols, flavonoids, tannins, polysaccharides, and sterol have been shown as ACE inhibitors [44]. These natural components are very important for preventing and treating hypertension. Flavonoids have been documented to inhibit different zinc metalloproteinases such as ACE, and anthocyanins, flavones, flavonols, and flavanols have been reported to have an inhibitory potential more than $\% 50$ of ACE. Furthermore, it has been exhibited that flavonoid-rich foods may lower blood pressure and inhibit ACE [45]. In addition, it has been revealed that edible plant components including peptides, flavonoids, and phenolic contents inhibit ACE activity [46,47]. Thus, in this study, two members of Apiaceae which are edible plants and rich in bioactive components were investigated as a potential ACE inhibitor [22,48]. With this aim, water extracts of $C$. sativum and $C$. macropodum were used to find their inhibitor potentials on human plasma ACE activity. To determine their inhibition potentials, the spectrometric method was used. Human plasma samples were treated with different concentrations of extracts. Then, Lineweaver-Burk graph was plotted for the determination of inhibition type with different FAPGG concentrations and different $C$. sativum and $C$. macropodum concentrations. Inhibition types were detected as reversible noncompetitive. The obtained results showed that $C$. sativum and $C$. macropodum have an inhibition potential on ACE activity in a dose-dependent manner with an $\mathrm{IC}_{50}$ value of $0.7 \mathrm{mg} / \mathrm{mL}$ and $1.14 \mathrm{mg} / \mathrm{mL}$, respectively as shown in Figure 1 and Figure 2. Inhibition types were detected as reversible noncompetitive (Figure 3 and Figure 4).

The obtained data are in accordance with previous reports in the literature. In a study, Hussain et al (2018) reported that $C$. sativum has ACE inhibition potential. In the study, researchers determined that fresh leaves of $C$. sativum have good inhibition potentials on ACE [49]. Moreover, they fractionated four secondary metabolites to find out actual bioactive compounds against the ACE activity. At the end of the study, they concluded that flavonoid-rich fraction has the most powerful ACE inhibitory effect and $\mathrm{IC}_{50}$ value was detected as $28.91 \mu \mathrm{g} / \mathrm{mL}$. In another work, Ali et al (2019) reported that methanolic extract of whole plants of Angelica decursiva has inhibitory effects against ACE [50]. Hyun et al (2013) reported that A. gigas and its coumarin constituents have a potential inhibitory effect on ACE [51]. In addition, it has been shown that Centella asiatica (Apiaceae) has an inhibition effect on ACE [52]. Simaratanamongkol et al (2014) concluded that methanolic extract of Apium graveolens, another member of apiaceae, showed important ACE inhibitory activity. They detected $\mathrm{IC}_{50}$ value as $1.7 \mathrm{mg} / \mathrm{mL}$ [53]. Suručić et al (2017) reported that essential oil of S.pallasii showed dose-dependent inhibition capacity on ACE with an $\mathrm{IC}_{50}$ value of $0.33 \mathrm{mg} / \mathrm{mL}$ [54]. In contrast to the results from our work, Saleem et al. (2017) stated that ethanol and water extracts of seeds of dill, ajowan, fennel, coriander, and anise from Apiaceae family did not show an inhibition effect on ACE [55]. This difference may be due to the extractions used in the study and bioactive component content. Similarly, Hussain et al (2018) reported that fresh leaves of $C$. sativum have high ACE inhibitory effect while the seeds of the plant did not have any ACE inhibitory affect [49].

In conclusion, the obtained results show that $C$. sativum and $C$. macropodum have an inhibitory affect on human plasma ACE activity in vitro. If these plants are used in an appropriate way, they can prevent cardiovascular diseases. But, further studies are needed to use this plant safety for treatment of hypertension. 


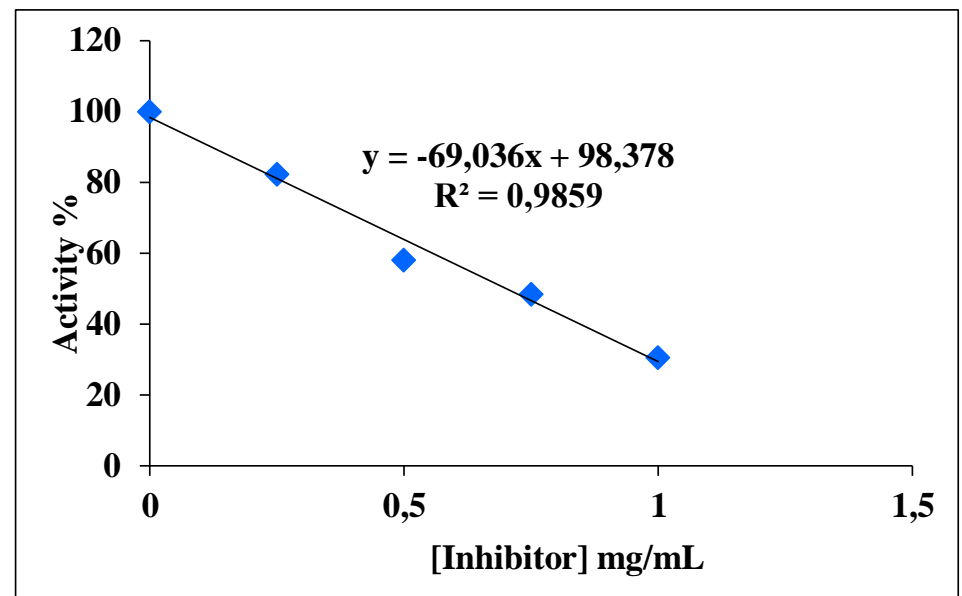

Figure 1. The inhibition effect of $C$. sativum L. extract on the ACE activity

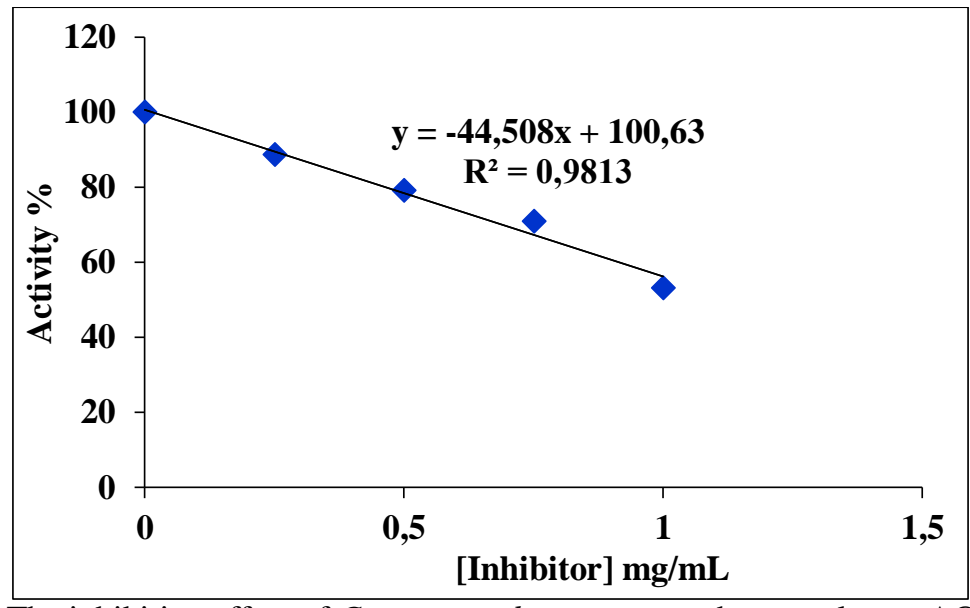

Figure 2. The inhibition effect of C. macropodum extract on human plasma ACE activity.

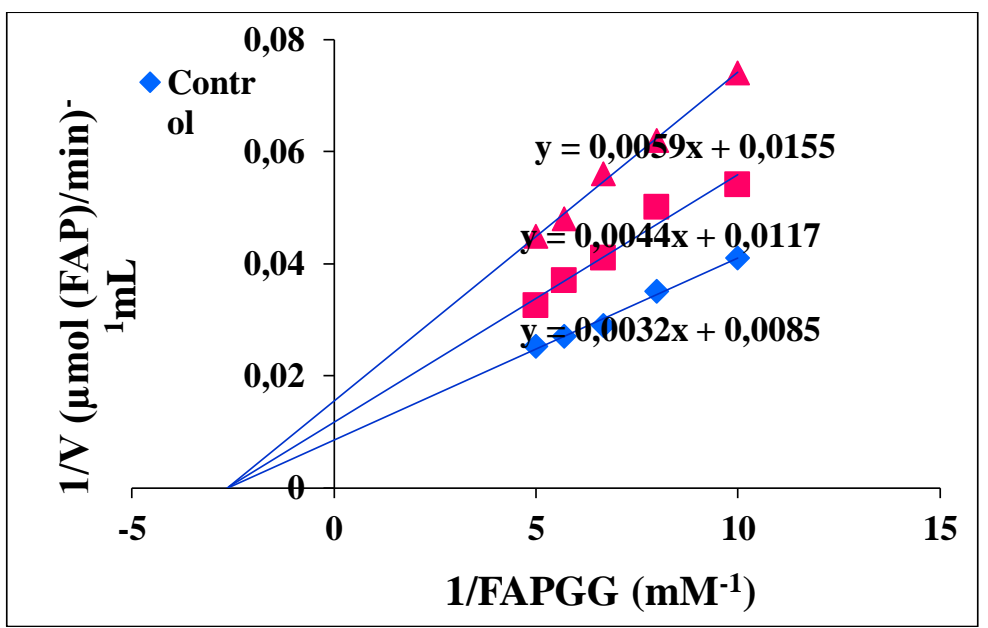

Figure 3. Lineweaver-Burk graph with different FAPGG concentrations. Two different $C$. sativum concentrations were used for the evaluation of inhibition type. 


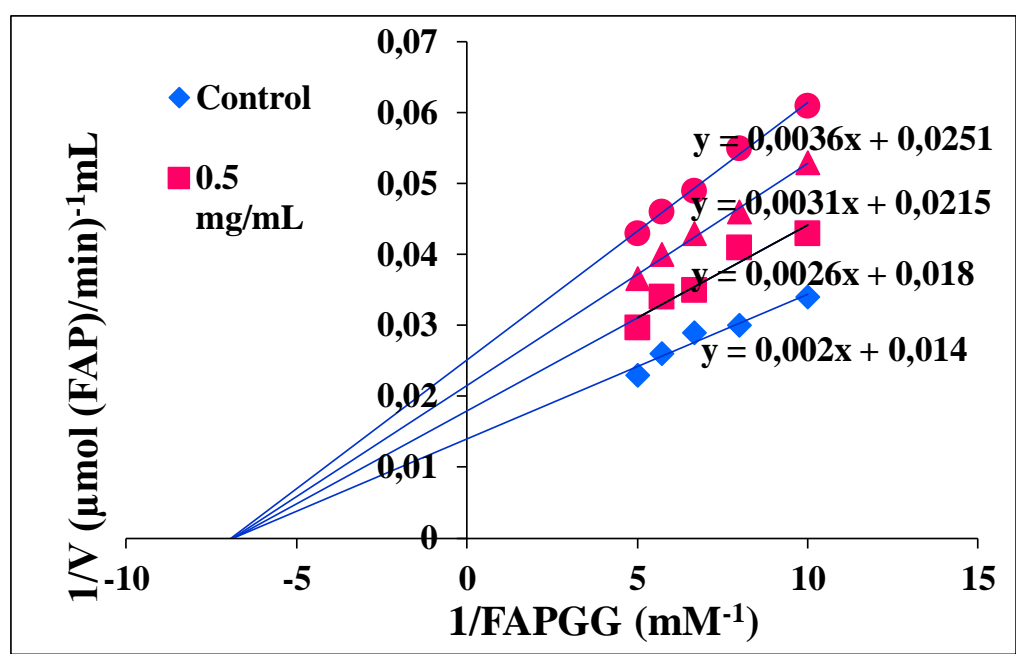

Figure 4. Lineweaver-Burk graph with different FAPGG concentrations and three different C. macropodum concentrations were used for the evaluation of inhibition type.

\section{Acknowledgement}

This work is supported by Bitlis Eren University Scientific Research Projects Office with Grant number BEBAP 2019.002.

\section{Author's Contributions}

Fatih Çağlar ÇELIKEZZEN and Vedat TÜRKOĞLU contributed to the planning of the study, literature review, experimental studies, writing and eveluation of the study results. Mehmet Firat took part in the collection and scientific diagnosis of plants. Zehra BAŞ took part in experimental studies and interpretation and writing of the results.

\section{Statement of Conflicts of Interest}

There is no conflict of interest among the authors.

\section{Statement of Research and Publication Ethics}

The authors declares that this study complies with Research and Publication Ethics.

\section{References}

[1] Bhagani S., Kapil V., Lobo M.D. 2018. Hypertension. Medicine, 46: 509-515.

[2] Wijesekara I., Kim S.K. 2010. Angiotensin-I-converting enzyme (ACE) inhibitors from marine resources: Prospects in the pharmaceutical industry. Marine Drugs, 8 (4): 1080-1093.

[3] Corvol P., Williams T.A., Soubrier F. 1995. Peptidyl dipeptidase A: angiotensin I converting enzyme. Methods Enzymology, 248: 283-305.

[4] Patten G.S., Abeywardena M.Y., Bennett L.E. 2016. Inhibition of angiotensin converting enzyme, angiotensin II receptor blocking and blood pressure lowering bioactivity across plant families. Critical Reviews in Food Science and Nutrition, 56 (2):181-214.

[5] Onat T, Emerk K, Sözmen E, 2006. İnsan Biyokimyas1, 2. Bask1, Palme Yayınc1lı, Ankara.

[6] Li G.H., Le G.W., Shi Y.H., Shrestha S. 2003. Angiotensin I - converting enzyme inhibitory peptides derived from food proteins and their physiological and pharmacological effects. Nutrition Research, 24: 469-486.

[7] Khong T.K., Adeyeye E. 2019. First-line drugs for hypertension. Drug and Therapeutics Bulletin, 57: 135-136. 
[8] Chen ZY, Peng C, Jiao R, Wong YM, Yang N, Huang Y, 2009. Antihypertensive nutraceuticals and functional foods. Journal of Agricultural and Food Chemistry, 57: 4485-4499.

[9] Azemi W.A.W.M., Samsudin N.A., Halim N.R.A., Sarbon N.M. 2016. Bioactivity of enzymatically prepared eel (Monopterus sp.) protein hydrolysate at different molecular weights. International Food Research Journal, 24 (2): 571-578.

[10] Baharuddin N.A., Halim N.R.A., Sarbon N.M. 2016. Effect of degree of hydrolysis (DH) on the functional properties and angiotensin I-converting enzyme (ACE) inhibitory activity of eel (Monopterus sp.) protein hydrolysate. International Food Research Journal, 23 (4): 1424-1431.

[11] Rho S.J., Lee J.S., Chung Y.I., Kim Y.W., Lee H.G. 2009. Purification and identification of an angiotensin I-converting enzyme inhibitory peptide from fermented soybean extract. Process Biochemistry, 44: 490-493.

[12] Hyun S.K., Lee H., Kang S.S., Chung H.Y., Choi J.S. 2009. Inhibitory activities of Cassia tora and its anthraquinone constituents on angiotensin-converting enzyme. Phytotherapy Research, 23: $178-184$.

[13] Kwon E.K., Lee D.Y., Hyungjae L., Kim D.O.K., Baek N.I.N., Kim Y.E., Kim H.Y. 2010. Flavonoids from the buds of Rosa damascena inhibit the activity of 3-hydroxy-3-methylglutarylcoenzyme a reductase and angiotensin I-converting enzyme. Journal of Agricultural and Food Chemistry, 58: 882-886.

[14] Gür T., Karahan F., Başı Z., Türkoğlu V. 2020. The Determination of Inhibition Effect of Extracts of Thymbra sintenisii Bornm. et Aznav. Subsp on Angiotensin Converting Enzyme. Journal of the Institute of Science and Technology, 10 (3): 1848-1856

[15] Sayed-Ahmad B., Talou T., Saad Z., Hijazi A., Merah O., 2017. The Apiaceae: Ethnomedicinal family as source for industrial uses. Industrial Crops and Products, 109: 661-671.

[16] Zengin G., Mahomoodally M.F., Paksoy M.Y., Carene Picot-Allain, Glamocilja J., Sokovic M., Diuzheva A., Jekő J., Cziáky Z., Rodrigues M.J., Sinan K.I., Custodio. 2019. Phytochemical characterization and bioactivities of five Apiaceae species: Natural sources for novel ingredients. Industrial Crops and Products, 135: 107-121.

[17] Özhatay N., Akalın E., Özhatay E., Ünlü S. 2009. Rare and endemic taxa of Apiaceae in Turkey and their conservation significance. Journal of Pharmacy of İstanbul University, 40: 1-9.

[18] Ngahang Kamte S.L., Ranjbarian F., Cianfaglione K., Sut S., Dall'Acqua S., Bruno M., Afshar F.H., Iannarelli R., Benelli G., Cappellacci L., Hofer A., Maggi F., Petrelli R., 2018. Identification of highly effective antitrypanosomal compounds in essential oils from the Apiaceae family. Ecotoxicology and Environmental Safety,156: 154-165.

[19] Demirci B, Koşar M, Demirci F, Dinç M, Başer KHC, 2007. Antimicrobial and antioxidant activities of the essential oil of Chaerophyllum libanoticum Boiss. et Kotschy. Food Chemistry,105 (4): 1512-1517.

[20] Çoruh N., Sağdıçoğlu Celep A.G., Özgökçe F. 2007. Antioxidant properties of Prangos ferulacea (L.) Lindl., Chaerophyllum macropodum Boiss. and Heracleum persicum Desf. from Apiaceae family used as food in Eastern Anatolia and their inhibitory effects on glutathione-S-transferase. Food Chemistry,100 (3): 1237-1242.

[21] Durmaz H., Sagun E., Tarakci Z., Ozgokçe F. 2006. Antibacterial activities of Allium vineale, Chaerophyllum macropodum and Prangos ferulacea. African Journal of Biotechnology, 5: 17951798.

[22] Ebrahimabadi A.H., Djafari-Bidgoli Z., Mazoochi A., Kashi F.J., Batooli H. 2010. Essential oils composition, antioxidant and antimicrobial activity of the leaves and flowers of Chaerophyllum macropodum Boiss. Food Control, 21: 1173-1178.

[23] Slavin J.L., Lloyd B.2012. Health benefits of fruits and vegetables. Advances in Nutrition, 3 (4): 506-516.

[24] Beyzi E., Karaman K., Gunes A., Beyzi S.B. 2017. Change in some biochemical and bioactive properties and essential oil composition of coriander seed (Coriandrum sativum L.) varieties from Turkey. Industrial Crops Products, 109: 74-78.

[25] Taherian A.A., Vafaei A.A., Ameri J. 2012. Opiate system mediate the antinociceptive effects of Coriandrum sativum in mice. Iranian Journal of Pharmaceutical Research, 11 (2): 679-688. 
[26] Aissaoui A., El-Hilaly J., Iaraili Z.H., Lyoussi B. 2008. Acute diuretic effect of continuous intravenous infusion of an aqueous extract of Coriandrum sativum L. in anesthetized rats. Journal of Ethnopharmacology, 115: 89-95.

[27] Gastón M.S., Cid M.P., Vázquez A.M., Decarlini M.F., Demmel G.I., Rossi L.I., Salvatierra N.A. 2016. Sedative effect of central administration of Coriandrum sativum essential oil and its major component linalool in neonatal chicks. Pharmaceutical Biology, 54 (10): 1954-1961.

[28] Jiao Y., Wang X., Chen J. 2021. Biofabrication of AuNPs using Coriandrum sativum leaf extract and their antioxidant, analgesic activity. Science of the Total Environment, 767: 144914.

[29] Patel D.K., Desai S.N., Devkar R.V., Ramachandran A.V. 2011. Coriandrum sativum L. aqueous extract mitigates high fat diet induced insulin resistance by controlling visceral adiposity in C57BL/6J Mice. Boletin Latinoamericano y del Caribe de Plantas Medicinales y Aromaticas, 10: 127-135.

[30] Medhin D.G., Hadhazy B.P., Verzar-Petri G. 1986. Hypotensive effects of Lupinus termis and Coriandrum sativum in anaesthetized rats. Acta Pharmaceutica Hungarica, 56: 59- 63.

[31] Özünlü O, Ergezer H. 2019. İnfüzyon yöntemi kullanılarak kurutulmuş enginar çanak yaprağ1 katk1lı soğuk yeşil çay üretimi. Akademik Gıda 17 (4): 458-467

[32] Andújar-Sánchez M., Cámara-Artigas A., Jara-Pérez V. 2003. Purification of angiotensin 1 converting enzyme from pig lung using concanavalin-A sepharose chromatography. Journal of Chromatography B, 783: 247-252.

[33] Holmquist B., Bünning P., Riordan J.F. 1979. A continuous spectrophotometric assay for angiotensin converting enzyme. Analytical Biochemistry, 95: 540-548.

[34] Singer P.S. 2019. Updates on hypertension and new guidelines. Adv. Pediatr. 66: 177-187

[35] Je J.Y., Park J.Y., Jung W.K., Park P.J., Kim S.K. 2005. Isolation of angiotensin I converting enzyme (ACE) inhibitor from fermented oyster sauce, Crassostrea gigas. Food Chemistry, 90 (4): 809-814.

[36] Paiva L., Lima E., Neto A.I., Baptista J. 2016. Angiotensin I-converting enzyme (ACE) inhibitory activity of Fucus spiralis macroalgae and influence of the extract's storage temperature-A short report. Journal of Pharmaceutical Biomedical Analysis, 30 (131): 503-507.

[37] Ma T.K., Kam K.K., Yan B.P., Lam Y.Y. 2010. Renin-angiotensin aldosterone system blockade for cardiovascular diseases: current status. British Journal of Pharmacology, 160 (6): 1273-1292.

[38] Lin L., Lu S., Harnly J. 2007. Detection and quantification of glycosylated flavonoid malonates in celery, Chinese celery, and celery seed by LC-DAD-ESI/ MS. Journal of Agricultural and Food Chemistry, 55: 1321-1326.

[39] Atanasov A.G., Waltenberger B., Wenzig E.M.P., Linder T., Wawrosch C., Uhrin P., Temml V., Wang L, Schwaiger S., Heiss E.H., Rollinger J.M., Schuster D., Breuss J.M., Bochkov V., Mihovilovic M.D., Kopp B., Bauer R., Dirscha V.M., Stuppner H. 2015. Discovery and resupply of pharmacologically active plant-derived natural products: a review. Biotechnology Advances 33: $1582-1614$.

[40] Dias D.A., Urban S., Roessner U. 2012. A historical overview of natural products in A historical overview of natural products in drug discovery. Metabolites, 2 (2): 303-336.

[41] Biswas D., Uddin M.M., Dizdarevic L.L., Jørgensen A., Duttaroy A.K. 2014. Inhibition of angiotensin-converting enzyme by aqueous extract of tomato. European Journal of Nutrition, 53 (8): 1699-1706.

[42] Hussain S.A., Panjagari N.R., Singh R.R.B., Patil G.R. 2015. Potential Herbs and Herbal Nutraceuticals: Food Applications and Their Interactions with Food Components, Critical Reviews in Food Science and Nutrition, 55 (1): 94-122.

[43] Huang W.Y., Davidge S.T., Wu J. 2013. Bioactive natural constituents from food sources potential use in hypertension prevention and treatment. Critical Reviews in Food Science and Nutrition, 53 (69): 615-630.

[44] Liu R.H., 2003. Health benefits of fruit and vegetables are from additive and synergistic combinations of phytochemicals. The American Journal of Clinical Nutrition, 78 (3): 517-520.

[45] Goretta L.A., Ottaviani J.I., Keen C.L., Fraga C.G. 2003. Inhibition of angiotensin converting enzyme (ACE) activity by flavan-3-ols and procyanidins. FEBS (Fed. Eur. Biochem. Soc.) Letter, 555: 597-60. 
[46] Dong J., Xu X., Liang Y., Head R., Bennett L. 2011. Inhibition of angiotensin converting enzyme (ACE) activity by polyphenols from tea (Camellia sinensis) and links to drug discovery. Metabolites 2: 303-336.

[47] Ojeda D., Jiménez-Ferrer E., Zamilpa A., Herrera-Arellano A., Tortoriello J., Alvarez L. 2010. Inhibition of angiotensin convertin enzyme (ACE) activity by the anthocyanins delphinidin-and cyanidin-3-O-sambubiosides from Hibiscus sabdariffa. Journal of Ethnopharmacology, 127 (1): 7-10.

[48] Wei J.N., Liu Z.H., Zhao Y.P., Zhao L.L., Xue T.K., Lan Q.K.2019. Phytochemical and bioactive profile of Coriandrum sativum L. Food Chemistry, 286: 260-267.

[49] Hussain F., Jahan N., Rahman K.U., Sultana B., Jamil S. 2018. Identification of Hypotensive Biofunctional Compounds of Coriandrum sativum and Evaluation of Their AngiotensinConverting Enzyme (ACE) Inhibition Potential. Oxidative Medicine and Cellular Longevity. 15: 4643736.

[50] Ali M.Y., Seong S.H., Jung H.A., Choi J.S. 2019. Angiotensin-I-converting enzyme inhibitory activity of coumarins from Angelica decursiva. Molecules, 24 (21): 3937.

[51] Hyun S.K., Oh Y.N., Kwon H.J., Kim B.W. 2013. Angiotensin converting enzyme inhibitory benzopyranoids from Angelica gigas. Food Science and Biotechnology, 22: 1741-1745.

[52] Hansen K., Nyman U., Smitt U.W., Adsersen A., Gudiksen L., Rajasekharan S., Pushpangadan P.1995. In vitro screening of traditional medicines for anti-hypertensive effect based on inhibition of the angiotensin converting enzyme (ACE). Journal of Ethnopharmacology, 48 (1): 43-51.

[53] Simaratanamongkol A., Umehara K., Noguchi H., Panichayupakaranant P. 2014. Identification of a new angiotensin-converting enzyme (ACE) inhibitor from Thai edible plants. Food Chemistry, 165: 92-97.

[54] Suručić R., Kundaković T., Lakušić B., Drakul D., Milovanović S.R., Kovačević N. 2017. Variations in Chemical Composition, Vasorelaxant and Angiotensin I-Converting Enzyme Inhibitory Activities of Essential Oil from Aerial Parts of Seseli pallasii Besser (Apiaceae). Chemistry Biodiversity, 14(5). doi: 10.1002/cbdv.201600407

[55] Saleem F., Sarkar D., Ankolekar C., Shetty K. 2017. Phenolic bioactives and associated antioxidant and anti-hyperglycemic functions of select species of Apiaceae family targeting for type 2 diabetes relevant nutraceuticals. Industrial Crops and Products, 107: 518-525. 